\title{
Passage of fish larvae and eggs through the Funil, Itutinga and Camargos Reservoirs on the upper Rio Grande (Minas Gerais, Brazil)
}

\author{
Fábio Mineo Suzuki, Lucas Vilela Pires and Paulo Santos Pompeu
}

\begin{abstract}
The objective of this study was to evaluate the passage of fish eggs and larvae through the Funil, Itutinga and Camargos Reservoirs, located in the upper Rio Grande basin, Minas Gerais, Brazil. Samples were taken downstream and upstream of the dams using a conical ichthyoplankton net and were collected every two weeks, twice per sampling day, between November 2008 and March 2009. Although eggs and larvae were abundant immediately upstream of the reservoirs, no ichthyoplankton were captured immediately downstream of the dams, possibly indicating that eggs and larvae do not pass through the reservoirs. The arrival of ichthyoplankton in the reservoirs without its effective passage downstream makes the survival of these eggs and larvae unlikely. Furthermore, this lack of downstream movement may compromise the recruitment of species to downstream stretches, especially in the case of the Funil Reservoir (because of the presence of a fish pass in this dam). We emphasize that the fish lift operation at the Funil Dam must be carefully assessed, considering not only its efficiency but also its short- and long-term effects on the recruitment of migratory fish species from the river.
\end{abstract}

O presente trabalho teve por objetivo avaliar a passagem de ovos e larvas através dos reservatórios de Funil, Itutinga e Camargos, localizados na bacia do alto rio Grande, Minas Gerais, Brasil. As amostragens foram realizadas a jusante e a montante das barragens com auxílio da rede de ictioplâncton cônica. Estas foram conduzidas quinzenalmente, duas vezes ao dia, entre novembro de 2008 e março de 2009. Apesar da elevada abundância de ovos e larvas imediatamente a montante dos reservatórios, não houve capturas de ictioplâncton imediatamente a jusante das barragens, indicando possivelmente a ausência de passagem de ovos e larvas pelos reservatórios do presente estudo. A chegada do ictioplâncton nos reservatórios sem a sua passagem efetiva à jusante torna sua sobrevivência pouco provável. Além disso, a falta desse movimento descendente pode comprometer o recrutamento das espécies aos trechos a jusante, especialmente no caso de Funil, em função da presença do mecanismo de transposição de peixes nessa barragem. Salientamos que a operação do elevador para peixes da barragem de Funil deve ser avaliada com cautela, considerando não apenas sua eficiência, mas também os efeitos a curto e longo prazo no recrutamento das espécies de peixes migradores do rio.

Key words: Conservation, Downstream migration, Ichthyoplankton, Migratory fish, Spawning.

\section{Introduction}

Migratory fish represent a small fraction of the Neotropical ichthyofauna (Petrere Jr., 1985). However, because of their sizes (Agostinho et al., 2003) and relatively high abundances (Northcote, 1978), these species are prized by professional and recreational fishermen (Agostinho et al., 2003).

Neotropical migratory fish are characterized by long seasonal migrations between different habitats to complete their life cycles (Carolsfeld et al., 2003). In addition to the migration of adults toward the spawning areas, their reproductive strategies involve other important processes, such as the return of adults and juveniles to feeding sites and the downstream drift of eggs and larvae toward rearing areas (floodplains and marginal lagoons) (Petrere Jr., 1985; Agostinho et al., 2003).
In an attempt to mitigate and minimize their impacts on migratory species, hydroelectric power plants have been required to build fish passes to facilitate fish movement (Sugunan, 1997). However, the efficiency of fish passes has been questioned because of their failures or negative effects on fish populations (Agostinho et al., 2002; Agostinho et al., 2007b; Agostinho et al., 2007c; Fernandez et al., 2004; Oldani et al., 2007; Makrakis et al., 2007). One reason fish passes have failed to preserve migratory fish populations is that it is difficult for eggs and larvae to pass through reservoirs (Agostinho \& Gomes, 1997; Agostinho et al., 2007a; Agostinho et al., 2007b). Although the transport of offspring to rearing areas is highly important, this process has been largely ignored, even when the spawning and rearing areas are located upstream and downstream of the dam, respectively (Clay, 1995). In such

Universidade Federal de Lavras, Campus Universitário, Pós Graduação em Ecologia Aplicada, Departamento de Biologia /Setor de Ecologia, Caixa Postal-3037, 37200-000 Lavras, MG, Brazil. fm.suzuki@hotmail.com (FMS) 
cases, the absence of downstream migration may negatively impact fish recruitment on both sides of the dam (Agostinho et al., 2007b).

The rio Grande basin is among the basins with the greatest hydroelectric potential in Brazil, making the study of fish egg and larval dynamics essential. Along the upper course of the river alone, there are four hydroelectric dams: Furnas, Funil, Itutinga and Camargos. The presence of these dams may be a critical factor in the success of fish recruitment in this basin. The reservoirs formed by the dams may be obstacles to ichthyoplankton transport toward favorable larval development areas, which may be found throughout the lotic remnants of the upper rio Grande. This information is even more important because the Funil Dam incorporates a fish pass mechanism in which many fish are transported upstream during the spawning season. Therefore, the purpose of this study was to evaluate the presence of fish spawn in the lotic remnants of the upper rio Grande and to determine the magnitude of downstream ichthyoplankton passage through the Funil, Itutinga and Camargos Reservoirs in the rio Grande basin, Minas Gerais, Brazil.

\section{Materials and Methods}

\section{Study area}

The Rio Grande drainage is part of the upper Paraná River basin and has an area of approximately $143,000 \mathrm{~km}^{2}$, of which $86,500 \mathrm{~km}^{2}$ is located in the state of Minas Gerais. It flows 1,300 $\mathrm{km}$ from the Mantiqueira Range to its confluence with the Paranaíba River, forming the Paraná River (Cemig \& Cetec, 2000). Four important hydroelectric dams are located along the main river channel in the upper Rio Grande basin: Furnas, Funil, Itutinga and Camargos (listed from downstream to upstream) (Table 1). Only the Funil Dam incorporates a fish pass, which consists of a fish lift. Although this basin has a high hydroelectric potential already installed, important lotic remnants are still found, mostly along the large tributaries that remain undammed, such as the Mortes, Capivari and Aiuruoca Rivers. The mouths of the Mortes and Capivari Rivers are influenced by the Funil Reservoir, whereas that of the Aiuruoca River is influenced by the Camargos Reservoir (Fig. 1). Flooded areas and marginal lagoons occur along the lotic remnants of the upper rio Grande basin, especially along the main river channel downstream of the Funil Dam and along the Aiuruoca and Mortes Rivers.

\section{Sampling}

We sampled ichthyoplankton at seven sites from November 2008 to March 2009. Four sites were located near the Funil Dam: immediately downstream of the dam (RGI), immediately upstream of the reservoir (RGII), near the mouth of the Mortes River (RM) and near the mouth of the Capivari River (RCA). We also sampled three sites near the Itutinga and Camargos hydroelectric power plants: downstream of the Itutinga Dam (RGIII), immediately upstream of the Camargos Reservoir (RGIV) and near the mouth of the Aiuruoca River (RA) (Fig. 1).

Samples taken from the RGI site were collected in the tailrace
Table 1. Technical data for the Funil, Itutinga and Camargos hydroelectric power plants located along the upper rio Grande, Minas Gerais, Brazil (http://www.cemig.com.br).

\begin{tabular}{lccc}
\hline \multicolumn{1}{c}{ Technical data } & \multicolumn{3}{c}{ Hydroelectric dam } \\
\cline { 2 - 4 } & Funil & Itutinga & Camargos \\
\hline Number and type of turbines & 3 (Kaplan) & 4 (Kaplan) & 2 (Kaplan) \\
Fish pass & Lift & - & - \\
Type of reservoir & Run of the & Run of the & Pumped \\
& river & river & storage \\
Maximum inundation area (km2) & 38.32 & 1.73 & 73.35 \\
Installed power (MWh) & 180 & 52 & 48 \\
Maximum reservoir volume (hm3) & 258 & 13 & 792 \\
\hline
\end{tabular}

channel before its confluence with the spillway channel, approximately 100 to $170 \mathrm{~m}$ from the dam wall (depending on the water level at the site). The outflow in this area consists of the turbine water and the drainage water from the fish pass mechanism. At the Itutinga Hydroelectric Dam, the RGIII samples were collected approximately $600 \mathrm{~m}$ from the dam wall, after the confluence with the spillway channel.

Larvae and eggs were collected every two weeks, twice per sampling day (morning and night) or weekly (morning). Morning samples were collected between 7:00 am and 9:00 am, and night samples were collected between 7:00 pm and 9:00 pm. Samples were collected weekly and only in the morning from the RGI sampling station. At each site, a conic ichthyoplankton net (500- $\mu \mathrm{m}$ mesh with a $40-\mathrm{cm}$ mouth diameter) containing a flow meter to estimate the filtered volume was placed approximately $2 \mathrm{~m}$ from one of the channel margins and submerged for $10 \mathrm{~min}$ in an area with relatively high water velocity. This sampling method has been adopted in other studies and has produced consistent data (Castro et al., 2002; Bialetzki et al., 2005; Ziober et al., 2007; Daga et al., 2009). Samples were fixed in $4 \%$ formalin and transported to the laboratory, where the material was sorted and identified on Bogorov plates using a stereomicroscope.

\section{Analysis}

Egg and larval densities of each sample were estimated and standardized per $10 \mathrm{~m}^{3}$ of filtered water. The larvae were identified to the lowest possible taxonomic level according to the method of Nakatani et al. (2001) and based on published lists of species from the upper rio Grande (Cemig \& Cetec, 2000; Pompeu et al., 2009). Organisms that could not be identified because of their developmental stages or structural damage were classified as "non-identified."

Daily river flow data for the sampling sites were obtained from the Energy Company of Minas Gerais (CEMIG). Mean water residence time (RT) in each reservoir was estimated monthly according to the following equation:

$\mathrm{RT}=\mathrm{V} /(\mathrm{Q} \times 86,400)$, where $\mathrm{V}=$ reservoir volume $\left(\mathrm{m}^{3}\right), \mathrm{Q}=$ mean monthly river discharge $\left(\mathrm{m}^{3} / \mathrm{s}\right)$ and $86,400=$ the number of seconds in a day. Because of the proximity of the Itutinga and Camargos Reservoirs, they were treated as a single reservoir (ItutingaCamargos; Fig. 1), and the residence time was estimated by adding their volumes. 


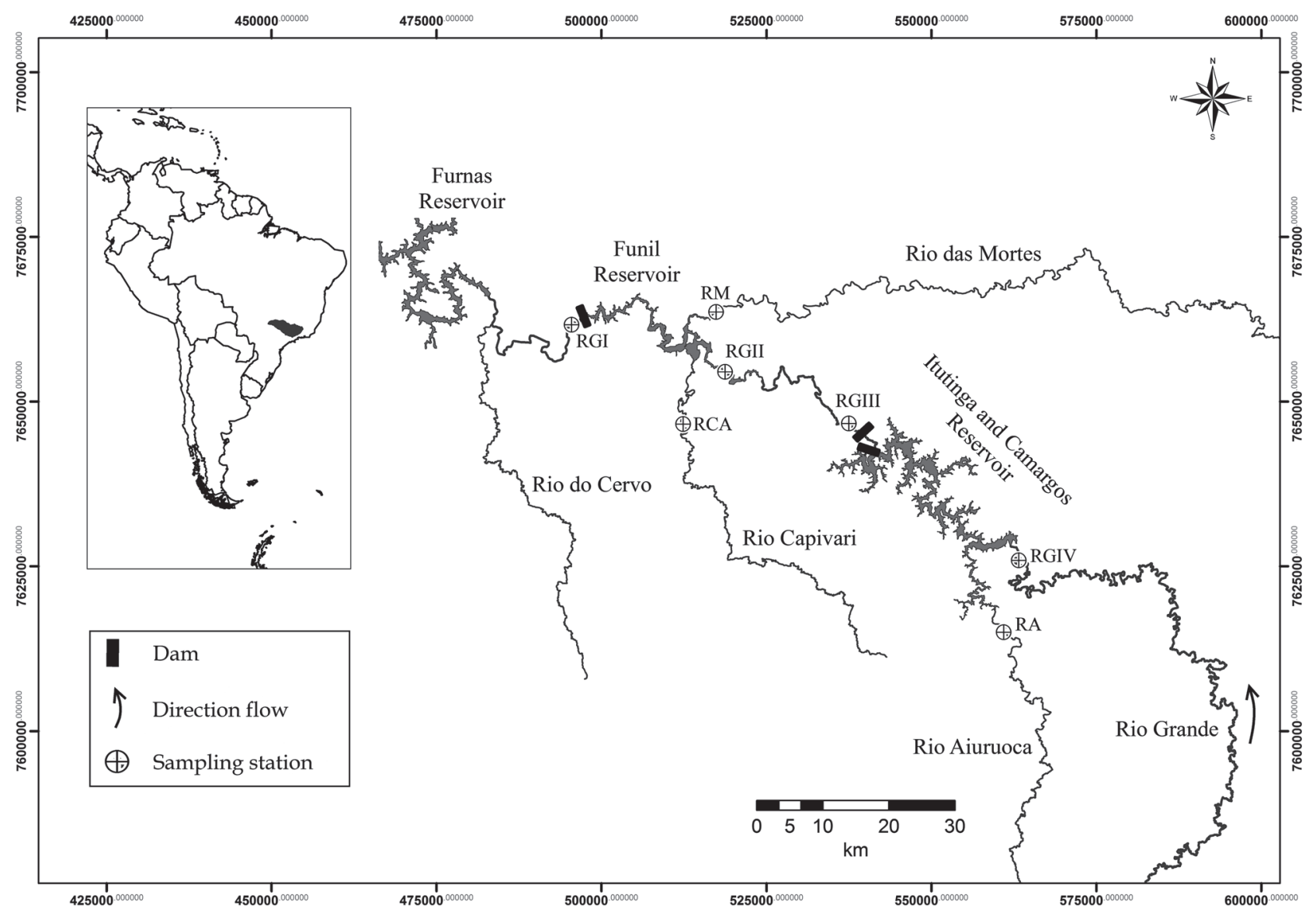

Fig. 1. Locations of sampling stations in the upper rio Grande basin upstream of the Furnas Reservoir (Minas Gerais State, Brazil). RGI = immediately downstream of the Funil Dam; RGII = immediately upstream of the Funil Reservoir; RGIII = immediately downstream of the Itutinga Dam; RGIV = immediately upstream of the Camargos Reservoir; RCA = Capivari River; RM = Mortes River; and RA = Aiuruoca River.

To estimate the total number of ichthyoplankton that arrived and left (passed) each reservoir per second during each sampling period, the egg and larval densities (mean number of ichthyoplankton per $\mathrm{m}^{3}$ of filtered water) were multiplied by the total river flow $\left(\mathrm{m}^{3} / \mathrm{s}\right)$.

The numbers of eggs and larvae reaching the Funil and Itutinga-Camargos Reservoirs (NMF and NMIC, respectively) per second and the numbers of eggs and larvae leaving these reservoirs $(\mathrm{NJ})$ per second were estimated every two weeks using the following equations:

$$
\begin{aligned}
& \mathrm{NMF}=\left[\left(D_{\mathrm{RGII}} \times \mathrm{Q}\right)+\left(D_{\mathrm{RCA}} \times \mathrm{Q}\right)+\left(D_{\mathrm{RM}} \times \mathrm{Q}\right)\right] \\
& \mathrm{NMIC}=\left[\left(\mathrm{D}_{\mathrm{RGIV}} \times \mathrm{Q}\right)+\left(\mathrm{D}_{\mathrm{RA}} \times \mathrm{Q}\right)\right] \\
& \mathrm{NJ}=\mathrm{D}_{\text {downstream of dam (Funil or trtutinga-Camargos) }} \times \mathrm{Q},
\end{aligned}
$$

where $\mathrm{D}=$ density of eggs or larvae and $\mathrm{Q}=$ river flow on the sampling day $\left(\mathrm{m}^{3} / \mathrm{s}\right)$.

Differences between the average number of eggs and larvae reaching and leaving the reservoirs per second were tested using non-parametric test statistic (Kruskal-Wallis).

\section{Results}

A total of 5,071 eggs and 198 larvae were captured during this study, all at sites located upstream of the reservoirs. The greatest abundance was found in the Funil tributaries, which yielded $63.9 \%$ of the eggs and $98.5 \%$ of the larvae captured. Among these ichthyoplankton, we identified seven taxonomic groups belonging to the orders Characiformes, Gymnotiformes and Siluriformes (Table 2).

During the study period, the average numbers of eggs and larvae reaching the Itutinga-Camargos Reservoir were estimated to be 700.07 and 0.73 per second, respectively, whereas those reaching the Funil Reservoir were 1,823.14 and 179.61 per second, respectively. Despite this substantial inflow of eggs and larvae into the reservoirs, ichthyoplankton were completely absent downstream of the studied dams, showing significant differences between the inflow and the outflow of eggs and larvae in these reservoirs (Kruskal-Wallis test, $\mathrm{p}<0.05$ ) (Fig. 2). 
Table 2. Number of eggs and larvae collected at each sampling site according to taxonomic group ( $\mathrm{RGI}=$ rio Grande immediately downstream of the Funil Dam; RGII = Rio Grande immediately upstream of the Funil Reservoir; RGIII = rio Grande immediately downstream of the Itutinga Dam; RGIV = rio Grande immediately upstream of the Camargos Reservoir; NI = non-identified larvae). *Larvae identified by order. $* \mathrm{NI}=$ Not Identified

\begin{tabular}{|c|c|c|c|c|c|c|}
\hline \multirow[t]{2}{*}{ Taxa } & \multicolumn{3}{|c|}{$\begin{array}{c}\text { Funil } \\
\text { Reservoir }\end{array}$} & \multicolumn{2}{|c|}{$\begin{array}{c}\text { Itutinga - Camargos } \\
\text { Reservoir }\end{array}$} & \multirow[t]{2}{*}{ Total } \\
\hline & RGI Capiva & Morte & RGII & $\overline{\text { RGIII Aiuruo }}$ & RGIV & \\
\hline Eggs & 1181 & 1745 & 315 & 1028 & 802 & 5071 \\
\hline \multicolumn{7}{|l|}{ Larvae } \\
\hline Characiformes* & & 5 & & 1 & & 6 \\
\hline Anostomidae & & 14 & 1 & & & 15 \\
\hline Characidae & 1 & 4 & & & & 5 \\
\hline Gymnotiformes* & 1 & & & & & 1 \\
\hline Siluriformes* & 4 & 93 & & & 2 & 99 \\
\hline Heptapteridae & & 8 & & & & 8 \\
\hline Pimelodidae & & 1 & & & & 1 \\
\hline NI & 11 & 52 & & & & 63 \\
\hline Total & 17 & 177 & 1 & 1 & 2 & 198 \\
\hline
\end{tabular}

Upstream from the studied reservoirs, the largest inflows of eggs and larvae were observed in December. At the Funil Hydroelectric Dam, the peak inflow was associated with a shorter water residence time in this reservoir, while the opposite pattern was observed at the Itutinga-Camargos Hydroelectric Dam (Fig. 3).

\section{Discussion}

Of the fish orders identified among the larvae collected in this study, only Gymnotiformes does not include migratory species. In the upper Paraná River basin, most migratory species belong to the orders Characiformes and Siluriformes, especially the families Characidae, Anostomidae and Pimelodidae (Agostinho et al., 2003). Based on the available species lists for the upper Rio Grande basin, nine important migratory species in this region are distributed among these three families (Cemig \& Cetec, 2000; Pompeu et al., 2009). Migratory species in the family Characidae include Brycon orbignyanus, Brycon nattereri, Salminus brasiliensis, Salminus hilarii and Piaractus mesopotamicus. Those in the family Anostomidae are Leporinus friderici and Leporinus obtusidens, and those in the family Pimelodidae are Pimelodus maculatus and Pseudoplatystoma corruscans. We cannot be certain that the larvae captured belonged to migratory species because they were identified only at the family level. However, considering the great abundance of the Leporinus, Pimelodus and Salminus species in the region (Alves et al., 1998), and since all of the eggs were non-adhesive, a characteristic of migratory fish (Rizzo et al., 2002), there is great potential of a significant part of the sampled ichthyoplankton belong to these species.

The lack of eggs and larvae captured downstream of the Funil and Itutinga-Camargos Reservoirs indicates that these structures possibly hinder or preclude the downstream movement of ichthyoplankton. Because eggs and larvae were captured in all tributaries of the reservoir, the absence of ichthyoplankton downstream of the reservoir cannot be attributed to the greater surface area and consequently greater dilution of the ichthyoplankton. We emphasize that, although we recorded no downstream passage of eggs and larvae during the study period, we cannot conclude that no ichthyoplankton pass through the reservoirs, since this study employed spot sampling, and no samples were taken from the body of the reservoir. However, the likelihood of ichthyoplankton passage is greatly reduced, especially at the same flow conditions. According to Agostinho et al. (2007b), reservoirs restrict the passive movement of ichthyoplankton in multiple ways. First, increased reservoir transparency increases the predation rate on ichthyoplankton by the small visual predators that are common in these environments (Agostinho \& Gomes, 1997; Agostinho et al., 2002; Agostinho et al., 2007b). Second, because of their limited mobility and the lentic conditions of the reservoir, ichthyoplankton sink to the bottom, where they suffocate because of low oxygen concentrations and high sedimentation rates (Agostinho et al., 2007b).

Agostinho et al. (2007b) have reported that the passage of ichthyoplankton through reservoirs depends mainly on reservoir size. Both the eggs and larvae of migratory species declined and then disappeared entirely in the lower half of the Lajedo Reservoir, which is located on the Tocantins River and has an area of $630 \mathrm{~km}^{2}$ (Agostinho et al., 2007b). On the other hand, results from the Santa Clara hydropower plant, which has a $7.5 \mathrm{~km}^{2}$ reservoir, indicate that some eggs and larvae pass through the reservoir. The short residence time of this reservoir (two days) and the low transparency of its water during floods may facilitate passage (Pompeu, 2005). The lack of ichthyoplankton passage through the reservoirs studied here may be due to their longer residence times and larger areas (approximately 4 days and $38.32 \mathrm{~km}^{2}$ for the Funil Reservoir and 14 days and $75.08 \mathrm{~km}^{2}$ for the Itutinga-Camargos Reservoir, respectively). The non-coincidence of peak larval and egg inflows with the shortest residence times in the reservoirs, especially for the Funil Dam, makes downstream passage even more unlikely.

Another critical aspect of the downstream movement of ichthyoplankton is their passage through dams with minimum mortality. This downstream transfer may occur in three ways: through turbines, spillways or the fish pass. The Hydroelectric Dam turbines at the dams studied here were in operation during all of the sampling dates, whereas the openings of the Funil and Itutinga Hydroelectric Dam spillways coincided with the collection of seven and five samples, respectively. Downstream of the Funil Hydroelectric Dam, the collection of the samples from the tailrace channel before its confluence with the spillway channel probably did not reduce the likelihood of ichthyoplankton capture when the spillway was open. This assumption is justified because the water intake of the turbine is located close to the level of the spillway, which resulted in similar chances of capture even during water spilling episodes. No published records have addressed the mortality rates of eggs and larvae resulting from passage through spillways. In turbines, friction with the water, impact with physical structures, sudden 

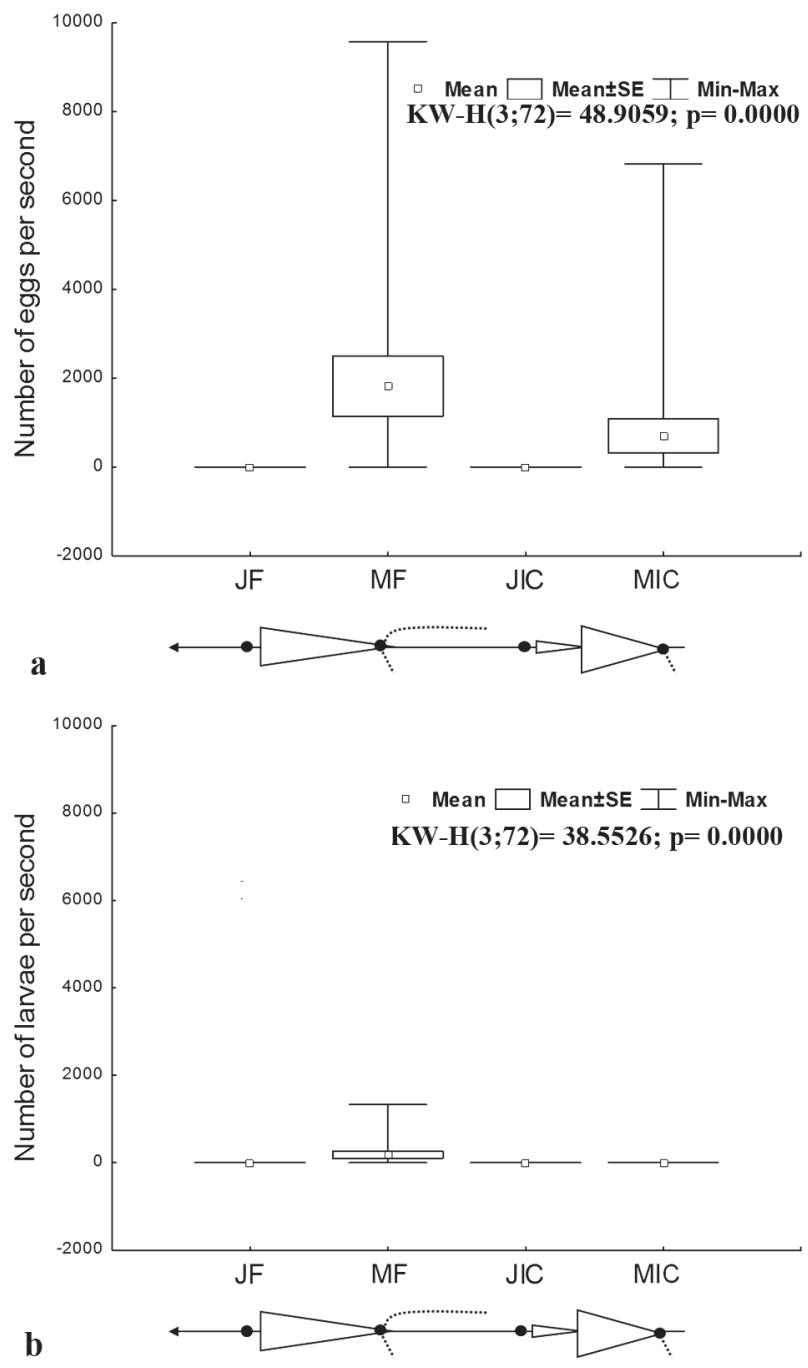

Fig. 2. Box plot of the number of eggs (a) and larvae (b) per second reaching the upstream and downstream regions of the Funil and Itutinga-Camargos Reservoirs from November 2008 to March 2009. Small open dots represent the tributaries sampled; triangles represent the reservoirs; black dots represent sites where numbers of eggs and larvae were estimated; and arrows represent the direction of flow $(\mathrm{JF}=$ downstream of the Funil Dam; MF = upstream of the Funil Reservoir; JIC = downstream of the Itutinga-Camargos Dam; and MIC = upstream of the Itutinga-Camargos Reservoir).

changes in pressure and cavitation are the main causes of death. Nevertheless, because both the likelihood of impact with the physical structures of the turbine and the pressure effects are correlated with the size of the individual organisms, less than 5\% of the ichthyoplankton are usually affected (Cada, 1990; 1991).

The impedance of the downstream movement of eggs and larvae by dams interrupts the life cycles of migratory fish, especially when the rearing areas (marginal lagoons) are located downstream of the dam. The loss of a significant portion of the ichthyoplankton in the reservoirs, associated with high natural
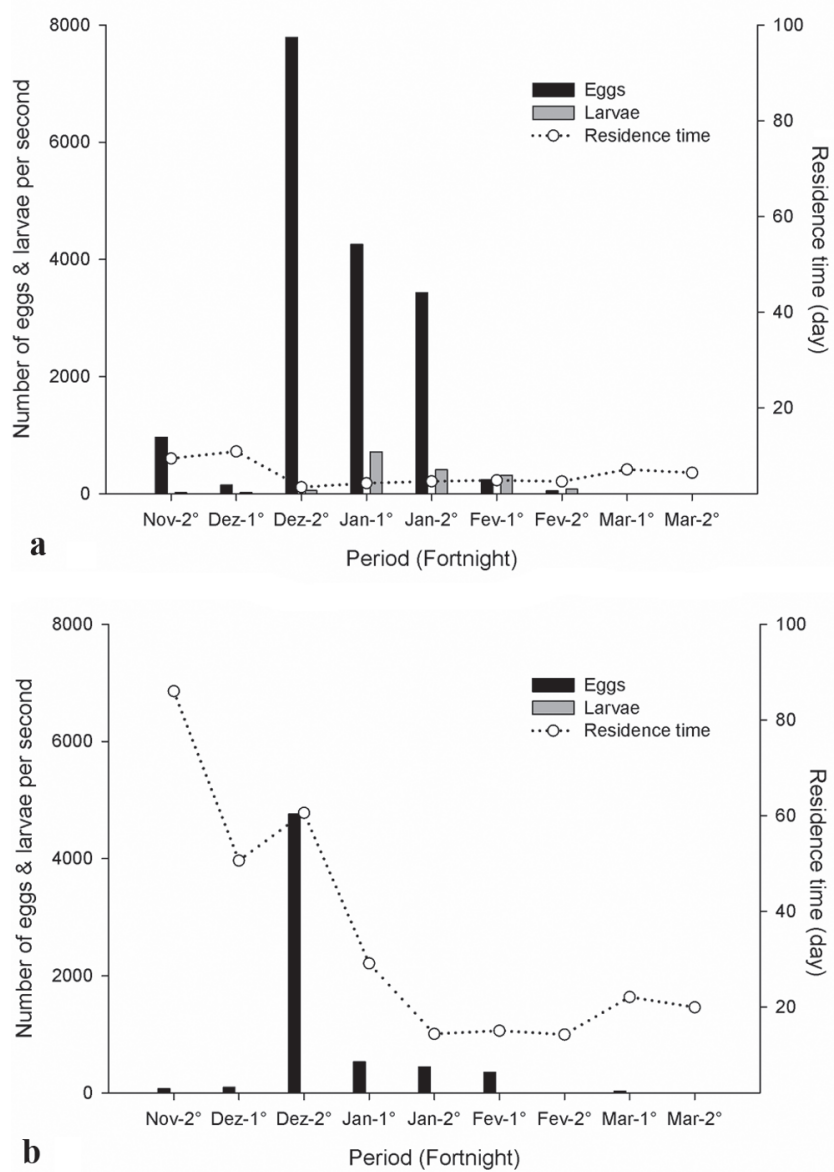

Fig. 3. Variation in mean water residence time (days) and estimated number of eggs and larvae per second reaching the Funil (a) and Itutinga-Camargos (b) Reservoirs from November 2008 to March 2009.

mortality rates, may have important long-term consequences on adult populations and entire lotic communities (Cada \& Hergenrader, 1978). The construction of a dam between areas that are critical for fish life cycles, such as spawning and rearing areas, increases the environmental impact of the dam (Agostinho et al., 2002). The Funil Reservoir appears to be such a case: several marginal lagoons can be found along the lotic remnants located mainly downstream of the dam (approximately $4 \mathrm{~km}$ downstream of the Funil Hydroelectric Dam), with varying degrees of environmental preservation. Long-term studies and adequate monitoring of the local ichthyofauna are needed because this impact may worsen, especially with the presence of the fish lift. At the Funil Dam, the upstream movement of migratory fish through the fish pass without effective downstream movement of their offspring, as observed here, is likely to reduce the recruitment of downstream populations. Notably, the presence of fish ladders has been identified as a major factor affecting the ichthyofauna at the Canoas I and II Hydroelectric Dams located on the Paranapanema River. Fish passage from downstream to upstream in the Canoas complex may be the cause of declining fish recruitment downstream of the dam (Lopes et 
al., 2007). These authors emphasize that preserving favorable areas for the completion of the reproductive cycle is more important than the functioning of fish passes. To avoid the depletion of fish stocks downstream of the Funil Dam, it is necessary to conduct adequate long-term studies and monitoring of the ichthyofauna both downstream and upstream of the dam, considering the areas that are critical for development and the possible need to limit the number of mature fish transported during the spawning season. It is also important to evaluate the role of marginal lagoons both downstream and upstream of the dam as habitat for the initial developmental stages of fish. The presence of these lagoons does not necessarily mean that fish use them as rearing areas.

Although upstream sections offer favorable spawning sites in our study area, reservoirs seem to prevent the downstream movement of offspring toward the floodplains located downstream from Funil Dam, making ichthyoplankton survival improbable. The fish pass at the Funil Dam must be rigorously evaluated, considering not only its efficiency but also its short- and long-term effects on the recruitment of migratory species in the river.

\section{Acknowledgements}

We thank Glycia Ferreira de Rezende, environmental educator at the Funil hydroelectric power plant, for invaluable help in sampling ichthyoplankton. We also thank Andréa Bialetzki for providing the internship opportunity, the Universidade Federal de Lavras for logistical help, FAPEMIG and FURNAS for funding this study, and R.M. Hughes for English editing.

\section{Literature Cited}

Agostinho, A. A. \& Gomes, L. C. 1997. Reservatório de Segredo: bases ecológicas para o manejo. Maringá, EDUEM, 387 p.

Agostinho, A. A., Gomes, L. C., Fernandez, D. R. \& Suzuki, H. I. 2002. Efficiency of fish ladders for neotropical ichthyofauna. River Research and Applications, 18: 299-306.

Agostinho, A. A., Gomes, L. C. \& Pelicice, F. M. 2007a. Ecologia e Manejo de Recursos Pesqueiros em Reservatórios do Brasil. Maringá, EDUEM, 512 p.

Agostinho, A. A., Gomes, L. C., Suzuki, I. S. \& Júlio Jr., H. F. 2003. Migratory fishes of the Upper Paraná River Basin, Brazil. Pp 19-98. In: Carolsfeld, J., Harvey, B., Ross, C. \& Baer, A. (Eds). Migratory fishes of South America: biology, fisheries and conservation status. Canadá, World Fisheries Trust, 380p.

Agostinho, A. A., Marques, E. E., Agostinho, C. S., De Almeida, D. A., De Oliveira, R. J. \& De Melo, J. R. B. 2007b. Fish ladder of Lajeado Dam: migrations on one-way routes? Neotropical Ichthyology, 5: 121-130.

Agostinho, C. S., Agostinho, A. A., Pelicice, F. M., De Almeida, D. A. \& Marques, E. E. 2007c. Selectivity of fish ladders: a bottleneck in Neotropical fish movement. Neotropical Ichthyology, 5: 205-213.

Alves, C. B. M., Godinho, A. L., Godinho, H. P. \& Torquato, V. C. 1998. A ictiofauna da represa de Itutinga, Rio Grande (Minas Gerais-Brasil). Revista Brasileira de Zoologia, 58: 259-263.

Cada, F. G. 1990. A review of studies relating to the effects of propeller- type turbine passage on fish early life stages. North American Journal of Fisheries Management, 10: 418-426.

Cada, F. G. 1991. Effects of hydroelectric turbine passage on fish early life stages. Water Power, 91: 318-326.

Cada, F. G. \& Hergenrader, G. L. 1978. An assessment of sampling mortality of larval fishes. Transactions of the American Fisheries Society, 107: 269-274.

Carolsfeld, J., Harvey, B., Ross, C. \& Baer, A. 2003. Migratory fishes of South America: biology, fisheries and conservation status. Canadá, World Fisheries Trust, 380 p.

Cemig \& Cetec. 2000. Guia ilustrado de peixes da bacia do rio Grande. Belo Horizonte, $141 \mathrm{p}$.

Clay, C. H. 1995. Design of fishways and other fish facilities. Boca Raton, Lewis Publishers, 248 p.

Fernandez, D. R., Agostinho, A. A. \& Bini, L. M. 2004. Selection of an experimental fish ladder located at the dam of the Itaipu Binacional, Paraná River, Brazil. Brazilian Archives of Biology and Technology, 47: 579-586.

Godinho, H. P. \& Godinho, A. L. 1994. Ecology and conservation of fish in southeastern Brazilian river basins submitted to hydroelectric impoundments. Acta Limnologica Brasiliensia, 5: 187-197.

Lopes, C. M., Almeida, F. S. D., Orsi, M. L., Britto, S. G. D. C., Sirol, R. N. \& Sodré, L. M. K. 2007. Fish passage ladders from Canoas Complex - Paranapanema River: evaluation of genetic structure maintenance of Salminus brasiliensis (Teleostei: Characiformes). Neotropical Ichthyology, 5: 131-138.

Makrakis, S., Makrakis, M. C., Wagner, R. L., Dias, J. H. P. \& Gomes, L. C. 2007. Utilization of the fish ladder at the Engenheiro Sergio Motta Dam, Brazil, by long distance migrating potamodromous species. Neotropical Ichthyology, 5: 197-204.

Nakatani, K., Agostinho, A. A., Baumgartner, G., Bialetzki, A., Sanches, P. V., Makrakis, M. C. \& Pavanelli, C. S. 2001. Ovos e larvas de peixes de água doce: desenvolvimento e manual de identificação. Maringá, EDUEM, 378 p.

Northcote, T. G. 1978. Migratory strategies in production in freshwater fishes. Pp 326-359. In: Gerking, S. D. (Eds). Ecology of freshwater fish production. Oxford, Blakwell Scientific Publications, 520p.

Oldani, N. O., Baigún, C. R. M., Nestler, J. M. \& Goodwin, R. A. 2007. Is fish passage technology saving fish resources in the lower La Plata River basin? Neotropical Ichthyology, 5: 89-102.

Petrere Jr., M. 1985. Migraciones de peces de agua dulce en América Latina: algunos comentarios. COPESCAL Documento Ocasional, $1: 1-17$.

Pompeu, P. S. 2005. Estudo da Regra Operativa e Avaliação de um Mecanismo de Transposição de Peixes do Tipo Elevador com Caminhão Tanque. Unpublished $\mathrm{PhD}$. Thesis, Universidade Federal de Minas Gerais, Belo Horizonte. 121 p.

Pompeu, P. S., Reis, L. S., Gandini, C. V., Souza, R. C. R. \& Favero, J. M. 2009. The ichthyofauna of upper rio Capivari: defining conservation strategies based on the composition and distribution of fish species. Neotropical Ichthyology, 27: 659-666.

Rizzo, E., Sato, Y., Barreto, B. P. \& Godinho, H. P. 2002. Adhesiveness and surface patterns of eggs in neotropical freshwater teleosts. Journal of Fish Biology, 61: 615-632.

Sugunan, V. V. 1997. Fisheries management of small water bodies in seven countries in Africa, Asia and Latin America. FAO Fisheries Circular, 933: 149p.

Submitted September 6, 2010

Accepted July 7, 2011

Published September 16, 2011 